\title{
Purification, characterization, and antiproliferative activity of L-methioninase from a new isolate of Bacillus haynesii JUB2
}

Brinda Bojamma Kotramada Bopaiah, Diana Aiyandra Nanda Kumar, Kohini Balan, Lucky Dehingia, Manoj Kumar Ramanayakanahalli Venkatesh Reddy, Ashrini Bhaktavalsala Suresh, Varalakshmi Kilingar Nadumane*

Department of Biotechnology, School of Sciences, Jain (Deemed-to-be-University), Jayanagar, India.

\begin{tabular}{l}
\hline ARTICLE INFO \\
\hline Received on: 03/06/2020 \\
Accepted on: 16/08/2020 \\
Available online: 05/10/2020 \\
\hline Key words: \\
Anticancer, Bacillus \\
haynesii, cytotoxic, ion- \\
exchange chromatography, \\
L-methioninase.
\end{tabular}

L-methioninase.

\begin{abstract}
L-methioninase (MGL) has received much attention in the recent years, since it shows antiproliferative activity and methionine restriction has been known to arrest tumor growth. Methionine dependence is the only known general metabolic defect in cancers. Normal cells have the ability to grow on homocysteine, instead of methionine, due to their active methionine synthase. Thus, depleting cellular/plasma methionine levels using MGL seems to be a promising therapeutic approach to treat cancer. Therefore, the objective of the present study is isolation of soil microbes using the selective M9 media for MGL producers and screening them for MGL activity. The results showed a novel bacterial strain, identified as Bacillus haynesii JUB2, which exhibited highest specific activity of $9.22 \mathrm{U} / \mathrm{mg}$ of protein. This enzyme was purified by acetone precipitation and diethylaminoethyl column methods. Upon column purification, fraction 6 yielded the highest enzyme activity and the specific activity increased enormously to $102.15 \mathrm{U} / \mathrm{mg}$ of protein. The cytotoxicity 3-(4,5-Dimethylthiazol-2-yl)-2,5-Diphenyltetrazolium bromide assay performed on breast (MCF-7) and liver cancer cell lines (HepG2) showed highest cytotoxicity with a percentage viability of 63.2 and 68.6, respectively, at $250 \mu \mathrm{g} / \mathrm{ml}$ concentration. It can be concluded that purified MGL from the new source of $B$. haynesii JUB2 holds promise toward anticancer studies.
\end{abstract}

\section{INTRODUCTION}

L-methioninase (EC 4.4.1.11; MGL), also termed L-methionine- $\gamma$-lyase, is a pyridoxal phosphate (PLP)-dependent hydrolytic enzyme which is known to catalyze the $\gamma$-elimination of L-methionine to generate $\alpha$-ketobutyrate, methanethiol (MTL), and ammonia, as well as the $\alpha, \beta$-replacement and $\beta$-elimination of S-substituted L-cysteines (Tanaka et al., 1983). MGL is a cytosolic enzyme inducibly formed by the addition of L-methionine to the culture medium (Lockwood and Coombs, 1991). It has a molecular weight between 149 and $173 \mathrm{kDa}$ and consists of four subunits with identical molecular weights of about $41-45 \mathrm{kDa}$ each; the purified enzyme has been reported to have a molecular mass of 47 KDa (Nakayama et al., 1984).

\footnotetext{
${ }^{*}$ Corresponding Author

K. N. Varalakshmi Department of Biotechnology, School of Sciences, Jain (Deemed-to-be-University), Jayanagar, India.

E-mail:kn.varalakshmi@jainuniversity.ac.in
}

In a healthy environment, mammalian cells possess the ability to proliferate on homocysteine, instead of methionine, due to their innate ability to produce methionine synthase (Mecham et al., 1983). In contrast, tumor cells lack efficient methionine synthase and thus rely on external methionine supplementation from the diet (Hoffman, 1984). Cancer cells also have an elevated requirement for methionine (MET) in comparison to normal cells. This phenomenon is termed MET dependence (Hoffman, 2015). Methionine restriction has been known to arrest tumor growth and to induce a selective S/G2-phase cell-cycle arrest of cancer cells both in vitro and in vivo (Guo et al., 1993; Hoffman and Jacobsen, 1980; Kokkinakis et al., 1997a; Kokkinakis et al., 1997b). Studies have also reported the disruption and abnormalities in methionine metabolism and transmethylation to be associated with the major disease in humans, like obesity, Parkinson's disease, heart disease, and cancer (Kreis and Hession, 1973).

Compounds and enzymes from natural sources have played vital roles in cancer drug discovery (Ashrini and Varalakshmi, 2016). Microbial MGL has received much attention in the recent years, since it shows antiproliferative activity toward 
various types of malignant cells (Cellarier et al., 2003). MGL is also one of the few microbial enzymes which possesses high therapeutic value, since its reporting as a potent anticancer agent against various types of tumor cell lines in breast, lung, colon, kidney, and glioblastoma (Kokkinakis et al., 2001; Tan et al., 2010). Tan and team reported the effective inhibition of the Yoshida sarcoma and human lung tumor with minimal toxicity in in vivo nude mice models after intraperitoneally injecting them with MGL (Tan et al., 1996). Thus, through many studies reporting activity of MGL, it has received affordable attention and has been widely studied for its various therapeutic potential, such as in cancer therapy and as antimicrobial drug (Alshehri, 2020; El-Sayed, 2011; Maggi and Scotti, 2019; Suganya et al., 2017), as a therapeutic agent against various types of methionine-dependent tumors.

MGL is present in most organisms, such as bacteria, fungi, protozoa, and plants. However, the enzyme is absent in mammals (Bhupender et al., 2014). MGL is produced as intracellular enzymes in most of the bacterial species. Both grampositive and gram-negative bacteria have been reported to produce MGL (Bhawana and Priyanka, 2018). Among prokaryotes, MGL is widely distributed in bacteria, especially in Pseudomonas spp., and is induced by the addition of L-methionine to the culture medium. From the studies reported so far, the bacteria appear to be the potent prokaryotes for enzyme production.

Current debate revolves around the low therapeutic efficiency and high levels of toxicity caused by a few bacterial MGL which increases the demand for new bacterial MGL producers, with lesser side effects and more efficiency (Kudou et al., 2007). Considering this as the main aim, we have screened a number of bacteria from various soil sources for their MGL activities. Among the different isolates, the bacteria belonging to Bacillus sp. was selected for the study. In the present work, we isolated, purified, and characterized MGL from Bacillus haynesii JUB2 and evaluated its in vitro anticancer activity.

\section{MATERIALS AND METHODS}

\section{Sample collection and isolation of microbes}

Various soil, gut (fish and lamb), and fecal (cow, lamb, and poultry) samples were collected from different locations in and around Karnataka, India. Serial dilution-plate method was used for the isolation of all the samples (Johnson et al., 1959). Nutrient agar medium was used for isolation of bacteria, containing $(\mathrm{g} / \mathrm{L})$ : peptone, 5.0; beef extract, 3.0; $\mathrm{NaCl}, 5.0$; and agar, 20.0. Czapek Dox Yeast agar medium was used for the isolation of fungi, containing $(\mathrm{g} / \mathrm{L})$ : sucrose, 30.0; $\mathrm{NaNO}_{3}, 3.0$; $\mathrm{K}_{2} \mathrm{HPO}_{4}, 1.0 ; \mathrm{MgSO}_{4}, 0.5 ; \mathrm{KCl}, 0.5 ; \mathrm{FeSO}_{4}, 0.01$; yeast extract, 5.0; and Agar, 20.0. The serially diluted plates were incubated at $37^{\circ} \mathrm{C}$ for 48 hours for bacterial isolates and at $28^{\circ} \mathrm{C}$ for 7 days for fungal isolates, and the developed pure culture colonies were further purified on their respective media.

\section{Screening for methioninolytic bacteria and fungi}

Qualitative rapid assay plate method was used to screen the bacterial and fungal isolates for their MGL productivities using modified M9 media containing (g/L): L-methionine, 5.0; glucose, 2.0; $\mathrm{Na}_{2} \mathrm{HPO}_{4}, 6.0 ; \mathrm{KH}_{2} \mathrm{PO}_{4}, 3.0 ; \mathrm{NaCl}, 0.5 ; \mathrm{MgSO}_{4} .7 \mathrm{H}_{2} \mathrm{O}, 0.5 ; \mathrm{CaCl}_{2}$, 0.01 ; and agar, 20.0. The final $\mathrm{pH}$ of the medium was adjusted to 7.0 and phenol red $(0.007 \%)$ was added to the medium as an indicator just before autoclaving (Sundar and Nellaiah, 2013a). The M9 plates were incubated at $37^{\circ} \mathrm{C}$ for 48 hours for bacterial isolates and at $28^{\circ} \mathrm{C}$ for 7 days for fungal isolates. Pink-colored colonies or growth forms resulting from the production of ammonia by the action of MGL on L-methionine were identified as MGL-producing isolates and were selected for further assays (Sundar and Nellaiah, 2013b).

\section{L-methioninase assay}

MGL activity was assayed according to a previously reported protocol. MTL produced from substrate L-methionine reacted with 5,5 dithio-bis-2-nitrobenzoicacid (DTNB; SigmaAldrich) to produce thionitrobenzoic acid which was detected at $412 \mathrm{~nm}$ using a spectrophotometer. The quantitative assay mixture in a final volume of $1 \mathrm{ml}$ consisted of $20 \mathrm{mM}$ of L-methionine in $0.05 \mathrm{M}$ potassium phosphate buffer of $\mathrm{pH} 7.0,0.01 \mathrm{mM}$ PLP (Sigma-Aldrich), $0.25 \mathrm{mM} \mathrm{DTNB}$, and $0.3 \mathrm{ml}$ of culture supernatant of the microbial isolate (i.e., the crude enzyme sample). Controls comprised heat denatured $\left(95^{\circ} \mathrm{C}\right.$ for 30 minutes $)$ culture supernatant. The developing yellow color of the assay mixture was read at $412 \mathrm{~nm}$ after an incubation period of 1 hour at $30^{\circ} \mathrm{C}$. A sodium methane thiolate standard graph was used to determine the amount of MTL released. One unit (U) of MGL was expressed as the amount of enzyme that releases $1 \mu$ mole of MTL per minute under optimal assay conditions (Selim et al., 2015a).

\section{Protein estimation}

The protein concentration in the culture supernatant was estimated by Lowry's method (Lowry et al., 1951) using bovine serum albumin $(200 \mu \mathrm{g} / \mathrm{ml})$ as the standard, which was spectrophotometrically read at $660 \mathrm{~nm}$.

\section{Identification of the isolate}

The best methioninolytic isolate was subjected to morphological and molecular characterization for identification. Preliminary identification was carried out based on microscopic and cultural observations by gram staining. Molecular identification of the promising bacterial isolate was performed by sequencing the conserved 16 s ribosomal RNA.

\section{L-methioninase enzyme purification}

Partial purification of the enzyme was carried out by the acetone precipitation method (Nejadi et al., 2014). Five volumes of pre-chilled absolute acetone were added to one volume of the sample and vortexed for 30 seconds. The precipitate was separated by centrifugation at $8,000 \mathrm{rpm}$ for 20 minutes at $4^{\circ} \mathrm{C}$. Supernatants were discarded and 5 volumes of pre-chilled $50 \%$ acetone were added to pellets and vortexed for 30 seconds. The supernatant was discarded and the pellet was air-dried.

\section{Ion exchange chromatography}

The dialysate comprising partially purified enzyme was mixed with $50 \mathrm{mM}$ acetate buffer ( $\mathrm{pH}$ 5.0). The mixture was centrifuged and the clear supernatant was used for purification in ion exchange chromatography. The diethylaminoethyl (DEAE) cellulose column was pre-equilibrated with $50 \mathrm{mM}$ acetate buffer (pH 5.0). After equilibration, the MGL fractions were eluted with a linear gradient of sodium chloride $(50 \mathrm{mM}-1 \mathrm{M})$ in the same 
buffer. The active fractions were collected, pooled, and assayed for their activity and enzyme concentrations (El-Sayed, 2011).

\section{Effect of temperature on the enzyme activity}

The optimum temperature of the purified enzyme was determined by incubating the reaction mixture for 1 hour at various temperatures $\left(25^{\circ} \mathrm{C}, 37^{\circ} \mathrm{C}, 40^{\circ} \mathrm{C}\right.$ and $\left.50^{\circ} \mathrm{C}\right)$, and then assaying their enzyme productivities. As there are many reports that say that the bacterial enzymes of Bacillus sp. best work in the range of $25^{\circ} \mathrm{C}-50^{\circ} \mathrm{C}$ (Agrawal et al., 2012; Rao and Narasu 2017; Yossana et al., 2006), these temperatures were chosen.

\section{Effect of pH on the enzyme activity}

The optimum $\mathrm{pH}$ of the purified enzyme was determined by using sodium citrate buffer $\mathrm{pH} 3.0-5.0$, phosphate buffer $\mathrm{pH}$ 6.0-8.0, and tris- $\mathrm{HCl}$ buffer $\mathrm{pH} 9.0-10.0$. The optimum $\mathrm{pH}$ of the enzyme was assayed by preincubating the enzyme solution at different $\mathrm{pH}$ values ranging from $\mathrm{pH} 3.0$ to 10.0 for 1 hour at $37^{\circ} \mathrm{C}$ and then determining the enzymatic activity.

\section{Screening for anticancer activity}

The effect caused by the crude enzyme, lyophilized acetone precipitated, and column purified fractions of the promising isolates was checked on human breast cancer cell line (MCF-7) and human liver cancer cell line (HepG2) by conducting 3-(4,5-Dimethylthiazol-2-yl)-2,5-Diphenyltetrazolium bromide (MTT) cell viability assay. MTT assay was performed on treated and control cells. The cells were seeded in 96-well plates and incubated for 24 hours at $37^{\circ} \mathrm{C}$ in a $5 \% \mathrm{CO} 2$ incubator for cell adhesion. $1,10,100$, and $250 \mu \mathrm{g} / \mathrm{ml}$ concentrations of the crude and $1,10,100,250$, and $500 \mu \mathrm{g} / \mathrm{ml}$ concentrations of the lyophilized fractions respectively, were added in triplicates and incubated for 48 hours. After the incubation period, $100 \mu \mathrm{l}$ of MTT solution was added to each well and the plates were incubated in the dark for 3 hours at $37^{\circ} \mathrm{C}$, after which $100 \mu \mathrm{l}$ of dimethyl sulfoxide was added to each well. The absorbance was recorded at $540 \mathrm{~nm}$ using an enzyme-linked immunosorbent assay plate reader (Mosmann, 1983). The percentage of cell viability was determined using the following formula:

Cell Viability $\%=$ Absorbance at $540 \mathrm{~nm}$ of the test sample / Absorbance at $540 \mathrm{~nm}$ of the control $\times 100$

\section{RESULTS AND DISSCUSSION}

\section{Screening for MGL production by bacteria and fungi}

Screening of various bacterial and fungal samples for their methioninolytic activity yielded five bacterial and eight fungal isolates, distinguished by their pink-colored colonies on selective M9 medium as a result of the generation of ammonia by the action of MGL on the substrate L-methionine. The screening profile (Table 1) shows the ability of different bacterial and fungal strains to produce MGL, their activity, protein content, and specific activity.

Among the various isolates grown on M9 medium, bacterial isolate designated as B2 demonstrated highest enzyme activity. Furthermore, data illustrated (Table 1) clearly showed that the incubation period did not affect the enzyme production as the highest enzyme production was obtained after 2 days of incubation in bacterial isolates, as compared to 5 days among the fungal isolates. Bacterial isolates demonstrated better enzymatic activity in comparison to the fungal isolates. As bacteria B2 produced the enzyme with highest activity of $7.38 \mu \mathrm{moles} / \mathrm{min} /$ $\mathrm{mL}$ and specific activity of $9.22 \mathrm{U} / \mathrm{mg}$ of protein, it was chosen as the best isolate for further experiments.

\section{Identification of the isolate $\mathbf{B 2}$}

Both gram-positive and gram-negative bacteria are known to be prolific producers of MGL (Bhawana and Priyanka, 2018). Preliminary identification was carried out based on morphological and colony characterization. The colonies were yellowish orange on nutrient agar (Fig. 1A) and pink colored on M9 medium. Microscopic evaluation by gram staining of the bacteria B2 showed purple single rods (Fig. 1B). Based on preliminary identification and morphological observations, the pigmented bacteria B2 was identified as gram-positive bacteria and to be a member of the Bacillus species.

Table 1. Screening for MGL production by bacterial and fungal isolates.

\begin{tabular}{lccc}
\hline Isolates & $\begin{array}{c}\text { MGL activity } \\
(\mu \text { moles/minute/ml })\end{array}$ & $\begin{array}{c}\text { Protein content } \\
(\mu \mathrm{g} / \mathrm{ml})\end{array}$ & $\begin{array}{c}\text { Specific activity } \\
(\mathrm{U} / \mathrm{mg} \text { protein })\end{array}$ \\
\hline Bacteria & & & \\
B1 & 0.11 & 800 & 0.13 \\
B2 & 7.38 & 800 & 9.22 \\
B3 & 2.00 & 800 & 2.50 \\
B4 & 0.47 & 800 & 0.58 \\
B5 & 0.35 & 800 & 0.43 \\
Fungi & & & \\
F1 & 0.35 & 4,100 & 0.08 \\
F2 & 0.23 & 4,700 & 0.04 \\
F3 & 0.35 & 3,150 & 0.10 \\
F4 & 0.58 & 3,700 & 0.15 \\
F5 & 0.35 & 2,800 & 0.12 \\
F6 & 0.35 & 2,850 & 0.13 \\
F7 & 0.58 & 3,650 & 0.15 \\
F8 & 0.23 & 2,700 & 0.08 \\
\hline
\end{tabular}

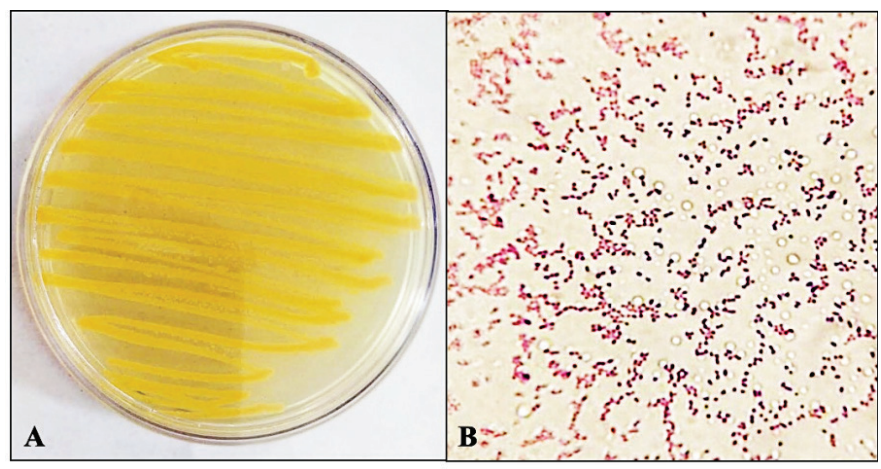

Figure 1. (A) The bacterial isolate (B2) pure culture on nutrient agar; (B) Microscopic view of gram-stained B2. 
16s rRNA gene sequencing is a routinely used method for the identification of bacterial species (Mignard and Flandrois, 2006). PCR amplification of 16s rDNA fragment from bacterial isolate B2 generated a PCR amplified product of size $\sim 1.5 \mathrm{~kb}$ (Fig. 2). Molecular identification further confirmed that the isolate belonged to the genus Bacillus and the $16 \mathrm{~S}$ ribosomal RNA gene sequence analysis indicated that the bacterial isolate B2 was a novel strain of $B$. haynesii, exhibiting $99 \%$ similarity to $B$. haynesii strain NRRL B-41327. The phylogenetic tree showing the relatedness of the species is shown in Figure 3. This isolate was named as B. haynesii JUB2 (Sequence ID: NR_157609).

\section{Purification of MGL}

Acetone precipitation is an easy and reliable purification method employed in most laboratories (Crowell et al., 2013). MGL was precipitated from the broth culture of $B$. haynesii JUB2 using acetone, followed by ion exchange chromatography. The

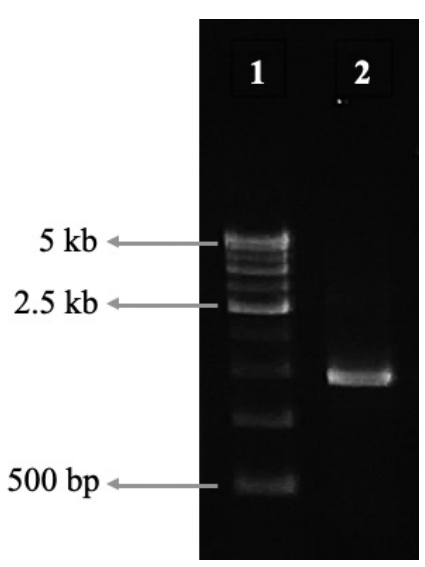

Figure 2. PCR amplification of $16 \mathrm{~s}$ rDNA fragment from bacterial isolate B2. The size of PCR amplified product was $\sim 1.5 \mathrm{~kb}$. Lanes 1: $500 \mathrm{bp}$ DNA Ladder; Lane 2: B2 isolated DNA. specific activity of MGL varied among the crude and the purified fractions.

Upon column purification, fraction 6 yielded the highest MGL activity of $19 \mu$ moles/minutes/ml with a much higher specific activity of $102.15 \mathrm{U} / \mathrm{mg}$ in comparison to the crude enzyme $(9.22 \mathrm{U} / \mathrm{mg})$ and acetone purified fraction $(0.018 \mathrm{U} / \mathrm{mg})$. In a recent study (Abdelraof et al., 2019), it was reported that MGL was purified through Sephadex-G column resulting in a 3.15-fold purification. As compared to the report in the current study, our isolated bacterial MGL after DEAE column purification exhibited specific activity of $102 \mathrm{U} / \mathrm{mg}$ of protein that is a 11-fold higher than the crude enzyme activity (Table 2). In another study report, under optimized conditions Bacillus subtilis had exhibited a specific activity of $19.60 \mathrm{U} / \mathrm{mg}$ of protein (Bhawana and Priyanka, 2018), while the Bacillus species in the present study yielded a 5-fold higher MGL activity as compared to this activity.

\section{Biochemical properties of MGL}

Optimum $\mathrm{pH}$

The enzyme activity was assayed at different $\mathrm{pH}$ 's ranging from $\mathrm{pH} 3.0$ to 9.0. Among the different $\mathrm{pH}$ buffers checked, the activity of MGL was found to be highest in tris- $\mathrm{HCl}$ buffer of $\mathrm{pH}$ 8.0-9.0, yielding $1.42 \mu$ moles/minutes/ml (Fig. 4). The control was set at $\mathrm{pH} 7.0$ which yielded the least activity. In an earlier study, the productivity of MGL from Aspergillus ustus increased by increasing the alkalinity of the medium to reach maximum yield at pH 8.5 (Abu-Tahon and Isaac, 2016) comparable with the current study. The enzyme in our study did not work in a $\mathrm{pH}$ range between 3.0 and 5.0. However, in a very recent report (Mohkam et al., 2020), a novel bacterial isolate, Alcaligenes sp., had a $\mathrm{pH}$ optima of 6.0 , i.e., in the acidic range.

\section{Optimum temperature}

Enzymes from bacterial sources usually work optimally at temperatures ranging between $25^{\circ} \mathrm{C}$ and $50^{\circ} \mathrm{C}$ or $55^{\circ} \mathrm{C}$ as

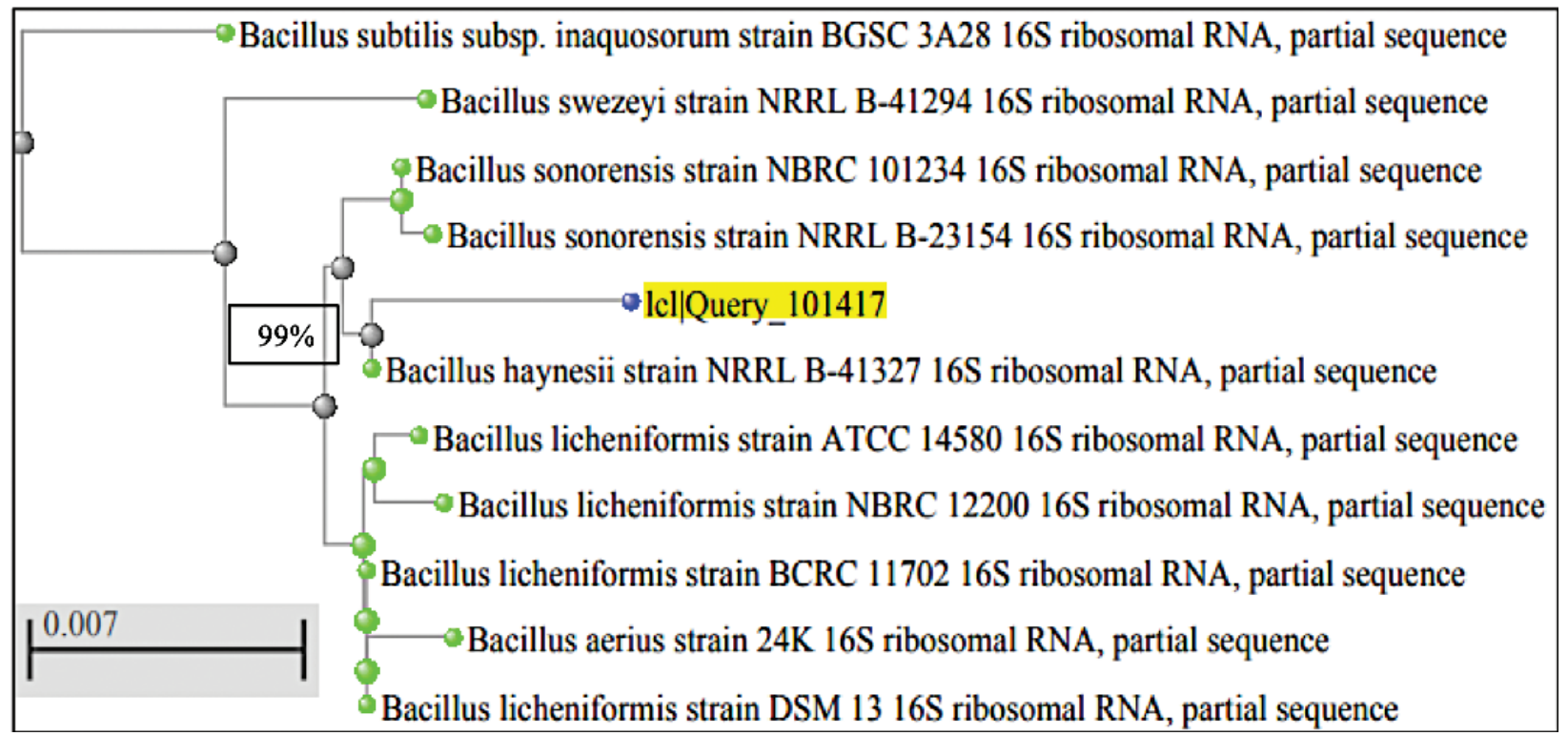

Figure 3. Phylogenetic analysis of the bacterial isolate B2. 
per reported literature and our previous studies (Agrawal et al., 2012; Rao and Narasu 2017; Varalakshmi et al., 2012; Yossana et al., 2006). Hence, in the present work, when the enzyme

Table 2. Purification folds and activity of B. haynesii JUB2.

\begin{tabular}{lcccc}
\hline Enzyme & $\begin{array}{c}\text { Enzymeactivity } \\
(\mu \text { moles/minute/ml })\end{array}$ & $\begin{array}{c}\text { Total protein } \\
(\mu \mathrm{g} / \mathrm{ml})\end{array}$ & $\begin{array}{c}\text { Specific activity } \\
(\mathrm{U} / \mathrm{mg} \text { protein })\end{array}$ & $\begin{array}{c}\text { Fold } \\
\text { increase }\end{array}$ \\
\hline Crude & 7.38 & 800 & 9.22 & 1 \\
Acetone purified & 0.0085 & 0.450 & 0.018 & - \\
Column purified & 19 & 0.183 & 102.15 & 11.07 \\
\hline
\end{tabular}

mixture was incubated at different temperatures $\left(25^{\circ} \mathrm{C}, 37^{\circ} \mathrm{C}\right.$, $40^{\circ} \mathrm{C}$ and $50^{\circ} \mathrm{C}$ ), the highest MGL activity was observed at $37^{\circ} \mathrm{C}$ and second best was at room temperature (i.e., control) at $28^{\circ} \mathrm{C} \pm 2{ }^{\circ} \mathrm{C}$. The activity decreased upon incubation at higher temperatures, remaining constant between $40^{\circ} \mathrm{C}$ and $50^{\circ} \mathrm{C}$ (Fig. 5). In accordance with the current study, MGL isolated from Hafnia alvei (Alshehri, 2020) and Alcaligenes sp. MT-B (Mohkam et al., 2020) under optimized conditions demonstrated the highest activity at $35 \mathrm{C}$. In a previous report, the optimum temperature for the MGL enzyme activity of Candida tropicalis was $45^{\circ} \mathrm{C}$ (Selim et al., 2015b) and the optimum temperature



Figure 4. Effect of different pH's on MGL activity from B. haynesii JUB2 $\left({ }^{*} p<0.05\right)$.

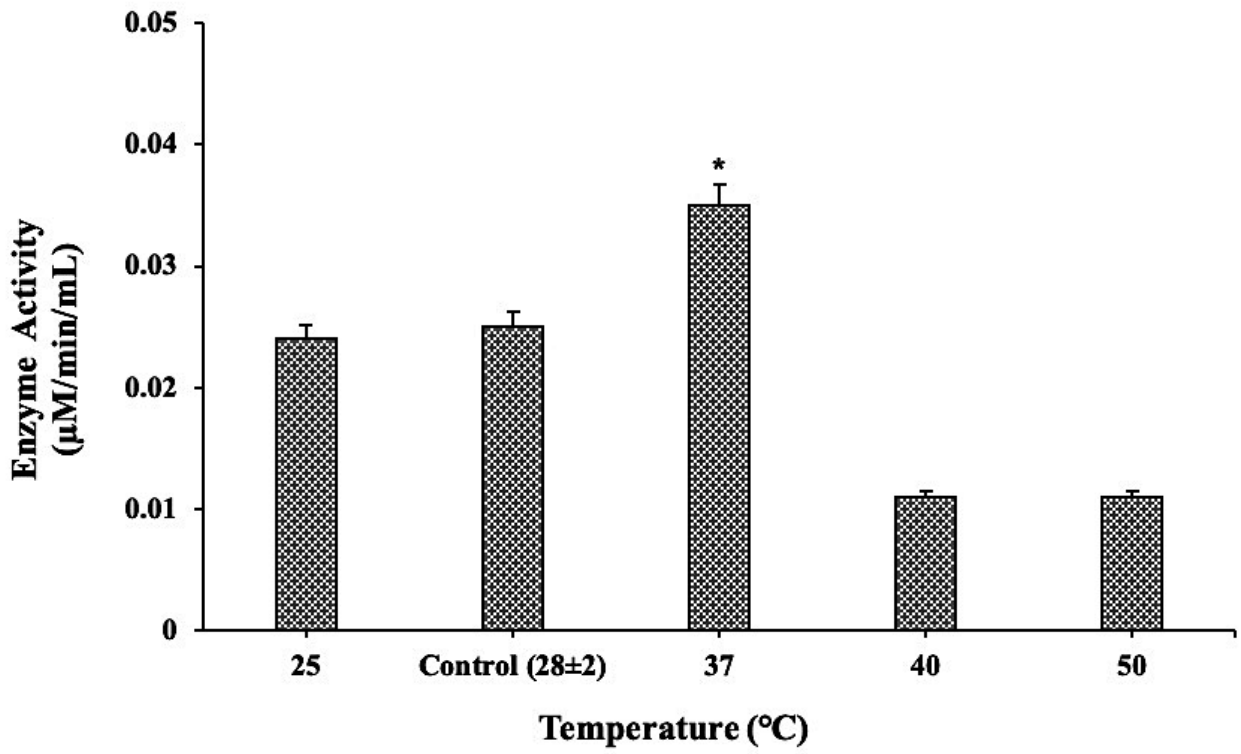

Figure 5. Effect of different temperatures on MGL activity from B. haynesii JUB2 $\left({ }^{*} p<0.05\right)$. 

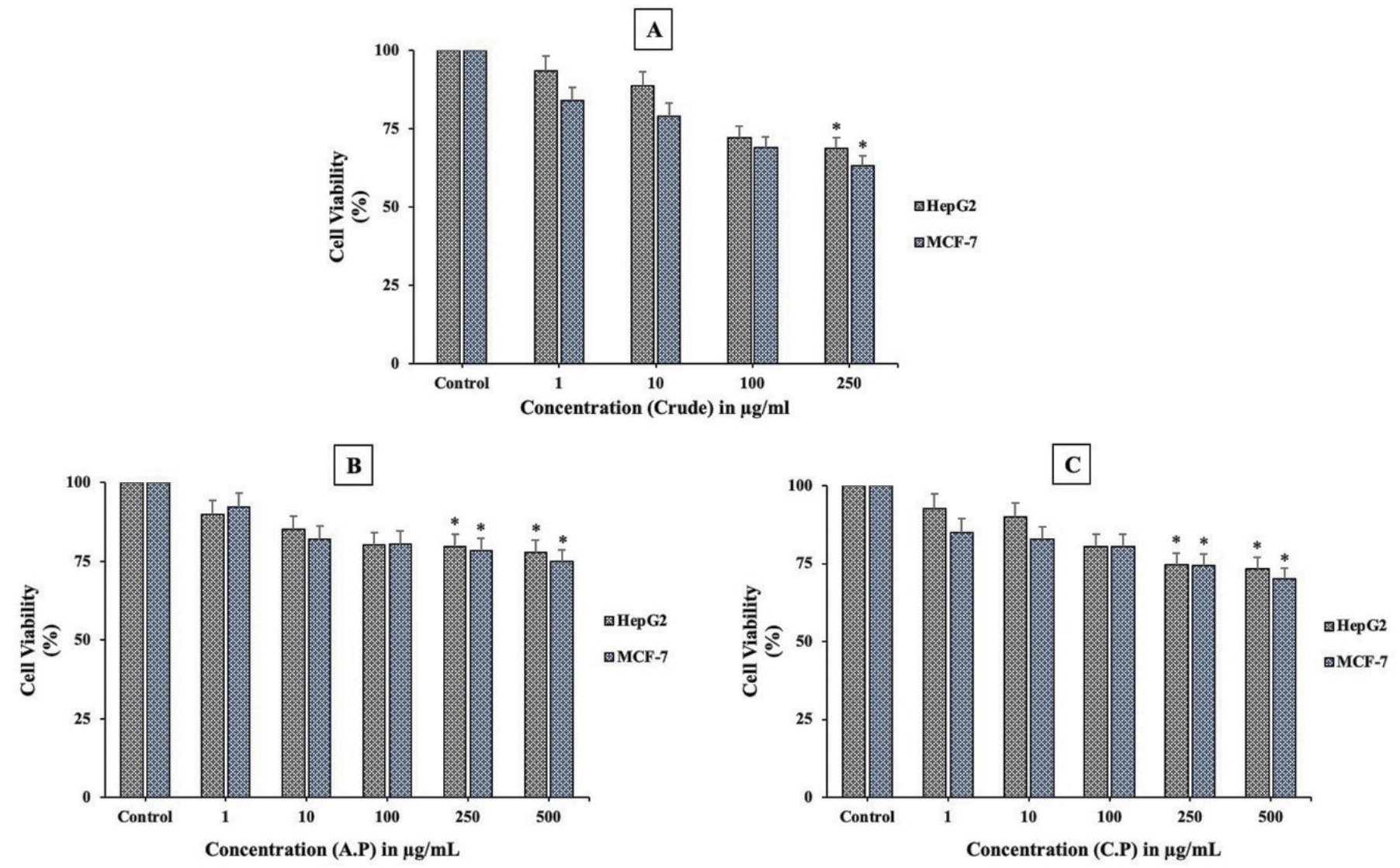

Figure 6. MTT assay of (A) crude extract; (B) acetone precipitate (A.P); and (C) column purified (C.P: Fraction 6) on HepG2 and MCF-7 cell viabilities when treated for 48 hours $(* p<0.05)$.

reported for MGL, purified from cheese lactic acid bacteria, was at $37^{\circ} \mathrm{C}$ (Hanniffy et al., 2009). All these studies are supportive of our observations about the temperature optima of MGL from B. haynesii in the current study.

\section{Cytotoxicity studies}

\section{MTT assay}

The efficiency of MGL against various cell lines was reported by many authors (Sundar and Nellaiah, 2013b; Tan et al., 2010). In the current study, cancer cells HepG2 and MCF-7 were treated with crude sample, acetone precipitated, and column purified (fraction 6) samples for 48 hours, as there are many studies that report and support the time period of either 24 or 48 hours to confirm the in-vitro anticancer potential of MGL (Huang et al., 2015; Selim et al., 2016). As per the results, the crude sample of MGL exhibited highest cytotoxicity with a percentage viability of 63.2 and 68.6 at $250 \mu \mathrm{g} / \mathrm{ml}$ concentration on MCF-7 and $\mathrm{HepG} 2$ cells, respectively (Fig. 6A). Column purified fraction 6 demonstrated a cell viability at $70 \%$ and $73.3 \%$ on MCF-7 and HepG2 cells, respectively, at a concentration of $500 \mu \mathrm{g} / \mathrm{ml}$ (Fig. 6C). The acetone precipitated sample yielded a cell viability of $74.9 \%$ and $77.8 \%$ on MCF-7 and HepG2 cells, respectively, at a concentration of $500 \mu \mathrm{g} / \mathrm{ml}$ (Fig. 6B). As compared to the purified enzyme samples, the crude sample was having higher cytotoxic effects on the treated cancer cell lines at lower treatment concentrations. We also observed that the effect of MGL on the viability of MCF-7 cell line was higher than that on HepG2 cell line, in accordance with an earlier report of MGL from $C$. tropicalis, the breast cancer cell line was more sensitive $\left(\mathrm{IC}_{50}\right.$ of $0.13 \mathrm{U} / \mathrm{ml}$ ) than liver cancer cell line $\left(\mathrm{IC}_{50} 0.2 \mathrm{U} / \mathrm{ml}\right)$ (Selim et al., 2015b). MGL was reported as a potent anticancer agent having $\mathrm{IC}_{50}$ values near to the standard drug doxorubicin in various cancer cells with $\mathrm{IC}_{50}$ value of $0.127 \mathrm{U} / \mathrm{ml}$ (Selim et al., 2016), which was once again evidenced through our current study results, hence showing the potential of MGL from the new isolate of B. haynesii toward cancer therapeutics.

\section{CONCLUSION}

In the current study, among the various isolates screened for MGL production, a new bacteria isolated from the Agumbe forest soil, of the Western Ghats, exhibited the highest specific activity. Based on macro and micro morphological features, the isolate was confirmed as belonging to the genus Bacillus. Sequencing of the conserved 16s rRNA region of the organism further confirmed it to be of a new strain of $B$. haynesii named as $B$. haynesii JUB2 and was deposited at GenBank (Sequence ID: NR_157609). The B. haynesii family has so far never been investigated for their MGL production, to the best of our knowledge. The crude MGL was subjected to acetone precipitation and DEAE cellulose column purification. The activity of MGL in the 6th fraction of the column purified 
sample was 11.07 -folds higher than the crude. The biochemical properties of the enzyme with respect to $\mathrm{pH}$ and temperature were investigated. The enzyme activity was highest at $\mathrm{pH} 8.0$ at a temperature of $37^{\circ} \mathrm{C}$ compared to the control of $\mathrm{pH} 7.0$ at a temperature of $28^{\circ} \mathrm{C}$. Lyophilized acetone precipitated and column purified fractions were checked for their anticancer potential through a MTT cell viability assay. Our data indicated that significant cytotoxicity was exhibited by the crude enzyme as well as acetone precipitated and column purified fractions on MCF-7 and HepG2 cancer cells, although further studies with higher concentrations and in-vivo studies would be necessary. From the current study we can conclude that purified MGL from a new source of $B$. haynesii JUB2 holds promise in anticancer studies. Further research toward complete characterization and statistical optimization of the enzyme production from $B$. haynesii JUB2 in addition to strain improvement studies can be of great pharmacological relevance.

\section{CONFLICT OF INTEREST}

Authors declared that there are no conflicts of interest.

\section{FUNDING}

None.

\section{REFERENCES}

Abdelraof M, Selim MH, Abo Elsoud MM, Ali MM. Statistically optimized production of extracellular L-methionine $\gamma$-lyase by Streptomyces Sp. DMMMH60 and evaluation of purified enzyme in subculturing cell lines. Biocatal Agric Biotechnol 2019; 18:101074.

Abu-Tahon MA, Isaac GS. Comparative study of a new alkaline L-methioninase production by Aspergillus ustus AUMC 10151 in submerged and solid-state fermentation. Braz Arch Biol Technol, 2016; 59:e16150484. Available via https://doi.org/10.1590/1678-4324-2016150484 (Accessed 04 August 2020).

Agrawal R, Singh R, Verma A, Panwar P, Verma AK. Partial purification and characterization of alkaline protease from Bacillus sp. isolated from soil. World J Agri Sci. 2012; 8:129-33.

Alshehri WA. Bacterium Hafnia alvei secretes L-methioninase enzyme: optimization of the enzyme secretion conditions. Saudi J Biol Sci, 2020; 27(5):1222-7.

Ashrini BS, Varalakshmi KN. Compounds from natural sources as potential anti-cancer agents: an in vitro study. Chem Sci Rev Lett, 2016; 5(18):86-92.

Bhawana K, Priyanka S. Microbial production of L-methioninase and its biotechnology application. Int J Recent Sci Res, 2018; 9(8C):28439-46.

Bhupender S, Sukhdev S, Shamsher SK. L-Methionase: a therapeutic enzyme to treat malignancies. Biomed Res Int, 2014; 1:1-13.

Cellarier E, Durando X, Vasson MP, Farages MC. Methionine dependency and cancer treatment. Cancer Treat Rev, 2003; 29:498-9.

Crowell AM, Wall MJ, Doucette AA. Maximizing recovery of water-soluble proteins through acetone precipitation. Analytica Chimica Acta, 2013; 796:48-54.

El-Sayed ASA. Purification and characterisation of a new L-Methioninase from soil cultures of Aspergillus flavipes. J Microbiol, 2011; 49(1):130-40.

Guo H, Lishko VK, Herrera H, Groce A, Kubota T, Hoffman RM. Therapeutic tumor-specific cell cycle block induced by methionine starvation in vivo. Cancer Res, 1993; 53:5676-9.

Hanniffy SB, Philo M, Peláez C, Gasson MJ, Requena T, Martínez-Cuesta MC. Heterologous production of methionine-gamma- lyase from Brevibacterium linens in Lactococcus lactis and formation of volatile sulfur compounds. Appl Environ Microbiol, 2009; 75(8):2326-32.

Hoffman RM. Altered methionine metabolism, DNA methylation and oncogene expression in carcinogenesis. Biochim Biophys Acta, 1984; 738:49-87.

Hoffman RM. Development of recombinant methioninase to target the general cancer-specific metabolic defect of methionine dependence: a 40-year odyssey. Expert Opin Biol Ther, 2015; $15: 21-31$

Hoffman RM, Jacobsen SJ. Reversible growth arrest in simian virus 40-transformed human fibroblasts. Proc Natl Acad Sci U S A, 1980; 77:7306-10.

Huang KY, Hu HY, Tang YL, Xia FG, Luo XQ, Liu JZ. Highlevel expression, purification and large-scale production of L-methionine $\gamma$-lyase from Idiomarina as a novel anti-leukemic drug. Mar Drugs, 2015; 13:5492-507; doi:10.3390/md13085492

Johnson LF, Curl EA, Bono JM, Fribourg HA. Methods for studying soil microflora plant disease relationships. Baltimore, MD, Minneapolis Publishing Co., p 178, 1959.

Kokkinakis DM, Hoffman RM, Frenkel EP, Wick JB, Han Q, Xu M, Tan Y, Schold, SC. Synergy between methionine stress and chemotherapy in the treatment of brain tumor xenografts in athymic mice. Cancer Res, 2001; 61(10):4017-23.

Kokkinakis DMA, von Wronski MA, Vuong TH, Brent TP, Schold SC Jr. Regulation of O6-methylguanine-DNA methyltransferase by methionine in human tumour cells. Br J Cancer, 1997a; 75:779-88.

Kokkinakis DMB, Schold SC Jr, Hori H, Nobori T. Effect of long-term depletion of plasma methionine on the growth and survival of human brain tumor xenografts in athymic mice. Nutr Cancer, 1997b; 29:195-204.

Kreis W, Hession C. Biological effects of enzymatic deprivation of L-methionine in cell culture and an experimental tumor. Cancer Res, 1973; 33(8):1866-9.

Kudou D, Misaki S, Yamashita M, Tamura T, Takakura T, Yoshioka T, Yagi W. Structure of the antitumor enzyme L-methionine -lyase from Pseudomonas putida at 1.80A resolution. Biochem J, 2007; 141:53544

Lockwood BC, Coombs GH. Purification and characterization of methionine $\gamma$-lyase from Trichomonas vaginalis. Biochem J, 1991; 279(3):675-82.

Lowry OH, Rosebrough NJ, Farr AL, Randall RJ. Protein measurement with the folin phenol reagent. J Biol Chem, 1951; 193(1):265-75.

Maggi M, Scotti C. Enzymes in metabolic anticancer therapy. In: Labrou N (ed.). Therapeutic enzymes: function and clinical implications. Berlin, Germany, Springer, pp 173-99, 2019.

Mecham JO, Rowitch D, Wallace CD, Stern PH, Hoffman RM. The metabolic defect of methionine dependence occurs frequently in human tumor cell lines. Biochem Biophys Res Commun, 1983; 117:429-34.

Mignard S, Flandrois JP.16S rRNA sequencing in routine bacterial identification: a 30-month experiment. J Microbiol Methods, 2006; 67(3):574-81.

Mohkam M, Taleban Y, Golkar N, Berenjian A, Dehshahri A, Mobasher MA, Ghasemi Y. Isolation and identification of novel L-methioninase producing bacteria and optimization of its production by experimental design method. Biocatal Agric Biotechnol, 2020; 26:101566. Available via https://doi.org/10.1016/j.bcab.2020.101566 (Accessed 04 August 2020).

Mosmann T. Rapid colorimetric assay for cellular growth and survival: application to proliferation and cytotoxicity assays. J Immuno Methods, 1983; 65(1-2):55-63.

Nakayama T, Esaki N, Sugie K, Beresov TT, Tanaka H, Soda K. Purification of bacterial $L$-methionine $\gamma$-lyase. Anal Biochem, 1984; 138(2):421-4 
Nejadi N, Masti SM, Tavirani MR, Golmohammadi T. Comparison of three routine protein precipitation methods: acetone, TCA/ acetone wash and TCA/acetone. J Pharm Sci, 2014; 5(4):58-60.

Rao K, Narasu ML. Alkaline protease from Bacillus firmus 7728. Afr J Biotechnol, 2017; 6:2493-6.

Selim MH, Elshikh HH, Saad MM, El-Sayed EM, Mahmoud MA Purification and characterization of a novel thermos stable L-Methioninase from Streptomyces sp. $\mathrm{DMMMH}_{4}$ and its evaluation for anticancer activity. J Appl Pharm Sci, 2016; 6(7):53-60.

Selim MHA, Elshikhb HH, El-Hadedyc ED, Saada MM, Eliwaa M, Abdelraofa M. L-methioninase from some Streptomyces isolates I: isolation, identification of best producers and some properties of the crude enzyme produced. J Genet Eng Biotechnol, 2015a; 13(2):129-37.

Selim MHB, Eldin, El-ZK, Saad MM, El-Sayed EM, Shetia YH, Anise AAH. Purification, characterization of L-methioninase from Candida tropicalis and its application as an anticancer. Biotechnol Res Int, 2015b; 2015:173140.

Suganya K, Govindan K, Prabha P, Murugan M. An extensive review on L-methioninase and its potential applications. Biocatal Agric Biotechnol, 2017; 12:104-15.

Sundar WA, Nellaiah HA. Production of methioninase from Serratia marcescens isolated from soil and its anti-cancer activity against Dalton's Lymphoma Ascitic (DLA) and Ehrlich Ascitic Carcinoma (EAC) in Swiss albino mice. Trop J Pharm Res, 2013a; 12(5):699-704.

Sundar WA, Nellaiah HB. A rapid method for screening of methioninase producing Serratia marcescens species from soil. Int J Pharm Sci, 2013b; 5(2):426-7.
Tan Y, Xu M, Guo H, Sun X, Kubota T, Hoffman RM. Anticancer efficiency of methioninase in vivo. Anticancer Res, 1996; 16:3931-6.

Tan Y, Xu M, Hoffman RM. Broad selective efficacy of rMETase and PEG-rMETase on cancer cells in vitro. Anticancer Res, 2010; 30(3):793-8.

Tanaka H, Esaki N, Soda K. 1983. Bacterial L-methionine gamma-lyase: characterization and application. Prog Clin Biol Res, 1983; 125:365-77.

Varalakshmi KN, Pallavi KN. Arpita B, Bhuvaneshwari S, Mrudula P, Priyanka G. Production and partial purification of $\alpha$-amylase from pseudomonas sp. 2 under solid-state fermentation. Turk J Biochem, 2012; 37(1):21-8.

Yossana S, Reungsangb A, Yasudac M. Purification and characterization of alkaline protease from Bacillus megaterium isolated from Thai fish sauce fermentation process. Sci Asia, 2006; 32:377-83.

\section{How to cite this article:}

Bopaiah BBK, Kumar DAN, Balan K, Dehingia L, Reddy MKRV, Suresh AB, Nadumane VK. Purification, characterization, and antiproliferative activity of L-methioninase from a new isolate of Bacillus haynesii JUB2. J Appl Pharm Sci, 2020; 10(10):054-061. 